\title{
ACCase inhibitor fractionation and glyphosate addition improve perennial sourgrass control
}

\section{O fracionamento de inibidores da ACCase e a adição de glyphosate melhoram o controle de capim-amargoso perenizado}

\author{
Guilherme Mendes Pio de Oliveira ${ }^{1 *}$; Marcelo Augusto de Aguiar e Silva ${ }^{2}$; \\ Giliardi Dalazen²
}

\section{Highlights}

Graminicide fractionation can improve sourgrass control.

Glyphosate addition potentiates graminicide action.

The order of FOP and DIM application affects sourgrass control.

\begin{abstract}
Glyphosate-resistant sourgrass is difficult to control, particularly when perennial, and strategies that improve the control efficiency against this grass and preserve the useful life of graminicides are warranted. Therefore, the present study aimed to answer the following questions: (i) Does fractionating the doses of ACCase inhibitors improve the control of perennial sourgrass? (ii) Does alternating the chemical groups cyclohexanediones (DIMs) and aryloxyphenoxypropanoates (FOPs) improve the control of perennial sourgrass, and does the order of their application affect sourgrass control efficiency? (iii) Does the addition of glyphosate to ACCase inhibitors improve to the control of perennial sourgrass resistant to 5-enol-pyruvyl-shiquime-3-phosphate synthase inhibitors? Two field experiments (I and II) were performed in 2018 and repeated in 2019. In experiment I, the treatments included a single or fractional application clethodim + quizalofop-P-ethyl $\left(216+108 \mathrm{~g}\right.$ a.i. ha-1), clethodim (216 $\mathrm{g}$ a.i. ha-1 ${ }^{-1}$, and quizalofop-P-tefuryl (108 $\mathrm{g}_{\text {a.i. }} \mathrm{ha}^{-1}$ ), applied in the order of clethodim followed by quizalofop-P-tefuryl and vice versa, as well as a control treatment. In experiment II, the treatments included a single or fractional application of clethodim + quizalofop-P-ethyl $\left(216+108 \mathrm{~g}\right.$ a.i. ha $\left.{ }^{-1}\right)$ and clethodim $(108 \mathrm{~g}$ a.i. ha-1 $)$, isolated or associated with glyphosate, as well as a control treatment. In both experiments, the interval between the fractional applications was 7 days. Percentage of control, number of tillers per plant, and height of sourgrass plants were determined. Compared with the unfractionated application, the fractionation of clethodim + quizalofop-P-ethyl and clethodim increased control by respectively 20-24 and 25-30\%. Fractionated clethodim has greater

1 Student of the Doctoral Course of the Postgraduate Program in Agronomy, Universidade Estadual de Londrina, UEL, Londrina, PR, Brazil. E-mail: guilhermemendespio@gmail.com

2 Profs. Drs., Postgraduate Program in Agronomy, Department of Agronomy, UEL, Londrina, PR, Brazil. E-mail: aguiaresilva@uel.br; giliardidalazen@gmail.com

* Author for correspondence
\end{abstract}

Received: Sept. 21, 2021 - Approved: Dec. 01, 2021 
control, and less regrowth and height of the sourgrass plants. The order of application of the chemical groups FOPs and DIMs affected control efficiency, and better results were obtained with the application of quizalofop-P-tefuryl followed by clethodim. The addition of glyphosate potentiates the action of graminicides, particularly when fractionated, even on resistant sourgrass, with a $26 \%$ increase in efficiency and resulting in satisfactory control (>80\%).

Key words: Clethodim. Digitaria insularis (L.) Fedde. ACCase inhibitors. Quizalofop. Sequential application.

\section{Resumo}

O capim-amargoso resistente ao glyphosate é difícil de controlar, principalmente quando perenizado, e estratégias que aumentem a eficiência de controle dessas plantas e preservem a vida útil dos graminicidas são necessárias. Portanto, o presente estudo teve como objetivo responder as seguintes perguntas: (i) $O$ fracionamento de doses de inibidores da ACCase melhora o controle de capim-amargoso perenizado? (ii) Alternar os grupos químicos ciclohexanodionas (DIMs) e ariloxifenoxipropanoatos (FOPs) melhora o controle de capim-amargoso perenizado, ea ordem de sua aplicação afeta a eficiência do controle de capimamargoso? (iii) A adição de glyphosate a inibidores da ACCase melhora o controle de capim-amargoso perenizado resistente aos inibidores da 5-enol-piruvil-shiquimato-3-fosfato-sintase? Foram realizados dois experimentos de campo (I e II) em 2018 e repetidos em 2019. No experimento I, os tratamentos incluíram aplicação única ou fracionada de clethodim + quizalofop-P-etílico (216 + $108 \mathrm{~g}$ i.a. ha-1), clethodim (216 g i.a. ha-1), e quizalofop-P-tefuril (108 g i.a. ha-1), aplicação de clethodim seguida de quizalofop-P-tefuril e viceversa, além de um tratamento controle. No experimento II, os tratamentos incluíram à aplicação única ou fracionada de clethodim + quizalofop-P-etílico $(216+108 \mathrm{~g}$ i.a. ha-1) e clethodim (108 g i.a. ha-1), isolados ou associados ao glyphosate, além de um tratamento controle. Em ambos os experimentos o intervalo entre as aplicações fracionadas foi de 7 dias. Determinou-se à porcentagem de controle, o número de perfilhos por planta, e à altura das plantas de capim-amargoso. Em comparação com a aplicação não fracionada, o fracionamento de clethodim + quizalofop-P-etílico e clethodim aumentou o controle em 2024 and $25-30 \%$, respectivamente. O clethodim fracionado apresentou maior controle, e menor rebrote e altura das plantas de capim-amargoso. A ordem de aplicação dos grupos químicos FOPs e DIMs afetou a eficiência do controle, e melhores resultados foram obtidos com a aplicação de quizalofop-P-tefuril seguido de clethodim. A adição de glyphosate potencializa a ação dos graminicidas, principalmente quando fracionados, mesmo sobre capim-amargoso resistente, com acréscimo de $26 \%$ na eficiência e resultando em controle satisfatório (>80\%).

Palavras-chave: Clethodim. Digitaria insularis (L.) Fedde. Inibidores da ACCase. Quizalofop. Aplicação sequencial.

\section{Introduction}

\section{Sourgrass (Digitaria insularis (L.)} Fedde) is one of the major agricultural weeds in Brazil, particularly in regions with mild winters, such as the northern parts of Paraná and the southeastern and midwestern parts of the country (Lopes Ovejero et al., 2017). In recent years, its occurrence has intensified because of the selection pressure exerted by the excessive use of glyphosate (Heap \& Duke, 2018) and the adoption of genetically 
modified Roundup Ready ${ }^{\circledR}$ (RR) cultivars, such as soybean (Glycine max (L.) Merril) and corn (Zea mays L.) (Gazola, Belapart, Castro, Cipola, \& Dias, 2016; Silveira, Langaro, Álcantara-de la Cruz, Sediyama, \& Silva, 2018).

In addition to glyphosate resistance, the invasive behavior of this weed is associated with its light and hairy seeds that can easily be dispersed over long distances via wind (L. J. P. Gomes, Santos, Gasparino, \& Correia, 2017). The seeds show high viability, germinating at a wide range of temperatures and light intensities (Mendonça, Martins, Martins, \& Costa, 2014), which guarantees their occurrence throughout the year (Silva, Karam, Vargas, \& Silva, 2017). Moreover, because of its numerous rhizomes, the plants grow vigorously by forming perennial clumps (L. J. P. Gomes et al., 2017). In addition, high dry matter biomass and lignin content of plant tissues (Gilo, Mendonça, Santo, \& Teodoro, 2016) limits the action of herbicides due to less translocation to root meristems. Thus, control at early stages, when plant tissues are less developed, allowing for herbicide absorption and translocation, is recommended (Fadin et al., 2018).

\section{Acetyl-CoA carboxylase (ACCase)} inhibitors are the primary herbicides used for the control of poaceae weeds (Andrade et al., 2018), particularly those resistant to glyphosate, including sourgrass. ACCase is responsiblefor the production of malonyl-CoA, which is a precursor of lipids (Cobb \& Reade, 2010). Aryloxyphenoxypropanoates (FOPs) and cyclohexanediones (DIMs) are the main chemical groups of ACCase inhibitors. Being selective for eudicot crops, such as soybean, bean (Phaseolus vulgaris L.), and cotton (Gossypium hirsutum L.), these herbicides are versatile in terms of their application period, in addition to compatibility with other active ingredients (Lancaster, Norsworthy, \& Scott, 2018). Thus, the combination of glyphosate with ACCase inhibitors is recommended for the control of perennial sourgrass, both in pre-wing and post-emergence desiccation phases of RR cultivars (Gilo et al., 2016).

To control perennial weeds, graminicide manufacturers recommend the application of higher doses of herbicides. However, the herbicide absorption capacity of plants is limited, and in some situations, high doses of herbicides inhibit their absorption and translocation (Nandula, Poston, Reddy, \& Koger, 2007). Additionally, when used at high doses, even systemic herbicides reduce the photosynthetic activity of plants and generate oxidative stress, causing tissue necrosis and vascular damage and limiting translocation (Radwan \& Soltan, 2012).

Thus, in such cases, fractional application of herbicides is proposed. In other words, the total dose of herbicides is divided into two applications. For instance, the application of haloxyfop and sethoxydim doses reduced by $50 \%$ of the total dose of each herbicide and divided into two applications has been proven effective in the control of alexandergrass (Urochloa plantaginea (Link) R.D. Webster) (Fleck, 1994). With the fractionation of ACCase inhibitors into two applications, another possibility opens up: the alternation of the chemical groups FOPs and DIMs, which is an important strategy to reduce the probability of development of resistance to ACCase inhibitors, since for most mutations, the resistance is not crossed for chemical groups (Powles \& Yu, 2010).

To this end, the objective of the present study was to answer the following questions: 
(i) Does the fractionation of doses of ACCase inhibitors improve the control of perennial sourgrass? (ii) Does the alternation of the chemical groups DIMs and FOPs improve the control of perennial sourgrass, and does the order of application affect control efficiency? (iii) Does the addition of glyphosate to ACCase inhibitors contribute to the control of perennial sourgrass resistant to 5-enolpyruvyl-shiquime-3-phosphate synthase (EPSPS) inhibitors?

\section{Material and Methods}

\section{Characterization of the experimental area}

Two field experiments were performed in 2018 and repeated in 2019. According to the Köppen-Geiger classification, the climate of the region is characterized as Cfa (humid subtropical temperate). The soil in the experimental area is classified as a Dystrophic Red Latosol, containing $12 \%$ sand, 36\% silt, and $52 \%$ clay; soil $\mathrm{pH}\left(\mathrm{CaCl}_{2}\right)$ is 4.8 , organic matter content is $20.1 \mathrm{~g} \mathrm{dm}^{-3}$, and cation exchange capacity is $8.8 \mathrm{cmol}_{\mathrm{c}} \mathrm{dm}^{-3}$.

The area where the experiments were conducted was fallow, with natural infestation of perennial sourgrass (6-8 plants per $\mathrm{m}^{2}$; plant height, $\sim 1.2 \mathrm{~m}$ ).

\section{Experimental design and treatments}

Both experiments were conducted in completely randomized blocks with four replicates. Each experimental unit measured $6.0 \mathrm{~m}$ in length and $4.0 \mathrm{~m}$ width $\left(24 \mathrm{~m}^{2}\right)$; the central area of each plot was considered useful for evaluation, and the $1 \mathrm{~m}$ border on each side of the plot was the neglected portion.

Experiment l: Fractionation and alternation of ACCase inhibitors for sourgrass control

The experiment included nine treatments, as shown in Table 1. As herbicides, the treatments constituted the ACCase inhibitors clethodim + quizalofop-Pethyl (Kroll ${ }^{\circledR}$ EC, $240+120 \mathrm{~g}$ a.i. $\left.\mathrm{L}^{-1}\right)$, clethodim (Select ${ }^{\circledR} 240$ EC, 240 g a.i. $\mathrm{L}^{-1}$ ), and quizalofopP-tefuryl (Panther ${ }^{\circledR} 120$ EC, 120 g a.i. L-1), applied at full doses in a single application [clethodim + quizalofop (216 + $108 \mathrm{~g}$ a.i. ha-1), clethodim (216 g a.i. ha-1), and quizalofop (108 ga.i. ha-1)] or fractionated into two applications [application A: clethodim + quizalofop (108 + $54 \mathrm{~g}$ a.i. ha-1), clethodim (108 $\mathrm{g}$ a.i. ha-1), and quizalofop (54 $\mathrm{g}$ a.i. ha-1); application $\mathrm{B}$, same combinations at 7 days after application $A]$. The effects of the application order were also evaluated using a treatment with the application of $50 \%$ of the dose of clethodim (application A), followed by the application of $50 \%$ of the dose of quizalofop (application B); in other treatments, the order of application of the herbicides was reversed. Alkyl ethoxylated phosphoric acid adjuvant (Lanzar $\left.{ }^{\circledR}\right)$ was added at $0.5 \%(v / v)$ to all graminicides. 


\section{Table 1}

\section{Treatments for the control of perennial sourgrass}

\begin{tabular}{|c|c|}
\hline \multicolumn{2}{|c|}{ Experiment I } \\
\hline Application A (g a.i. ha-1) & Application B (g a.i. ha-1) \\
\hline Clethodim + Quizalofop $(216+108)$ & - \\
\hline Clethodim + Quizalofop $(108+54)$ & Clethodim + Quizalofop $(108+54)$ \\
\hline Clethodim (216) & - \\
\hline Clethodim (108) & Clethodim (108) \\
\hline Quizalofop (108) & - \\
\hline Quizalofop (54) & Quizalofop (54) \\
\hline Clethodim (108) & Quizalofop (54) \\
\hline Quizalofop (54) & Clethodim (108) \\
\hline Control & Control \\
\hline \multicolumn{2}{|c|}{ Experiment /I } \\
\hline Application A (g a.i. ha-1) & Application B (g a.i. ha-1) \\
\hline Clethodim + Quizalofop $(216+108)$ & - \\
\hline Clethodim + Quizalofop $(108+54)$ & Clethodim + Quizalofop $(108+54)$ \\
\hline Clethodim + Quizalofop $(216+108)+$ Glyphosate (1080) & - \\
\hline Clethodim + Quizalofop $(108+54)+$ Glyphosate (1080) & Clethodim + Quizalofop $(108+54)$ \\
\hline Clethodim (216) & - \\
\hline Clethodim (108) & Clethodim (108) \\
\hline Clethodim (216) + Glyphosate (1080) & - \\
\hline Clethodim (108) + Glyphosate (1080) & Clethodim (108) \\
\hline Control & Control \\
\hline
\end{tabular}

a.i.: active ingredient.

Experiment II: Effect of glyphosate addition to ACCase inhibitors for the control of EPSPS inhibitor-resistant perennial sourgrass

The treatments in experiment II (Table 1) were organized in a $2 \times 2 \times 2$ factorial scheme, in addition to a control treatment. Factor A involved the application of the ACCase inhibitor herbicides clethodim + quizalofop-P-ethyl (Kroll ${ }^{\circledR}$ EC, $240+120 \mathrm{~g}$ a.i. $\mathrm{L}^{-1}$ ) and clethodim (Select ${ }^{\circledR} 240$ EC, $240 \mathrm{~g}$ a.i. $\left.\mathrm{L}^{-1}\right)$. These herbicides were selected because of the best results obtained in experiment
I. Factor B corresponded to the application forms of the herbicides: in a single application or fractionated into two applications, at an interval of 7 days. Factor $\mathrm{C}$ corresponded to the addition or not of glyphosate (Crucial ${ }^{\circledR}$, $400.8 \mathrm{~g} \mathrm{~L}^{-1}$ of glyphosate-isopropylamine salt $+297.75 \mathrm{~g} \mathrm{~L}^{-1}$ of glyphosate potassium salt) at a dose of $1,080 \mathrm{~g}$ a.e. ha $^{-1}$, equivalent to $2.0 \mathrm{~L} \mathrm{ha}^{-1}$ of the commercial product. Alkyl ethoxylated phosphoric acid adjuvant ( Lanzar $^{\circledR}$ ) was added at $0.5 \%(\mathrm{v} / \mathrm{v})$ to the spray solution. 


\section{Treatment application}

In both experiments, the treatments were applied using a $\mathrm{CO}_{2}$ pressurized backpack sprayer equipped with a $3 \mathrm{~m}$ bar constituting pre-orifice flat-fan ADI 11002 spray nozzles attached $0.5 \mathrm{~m}$ apart and $0.5 \mathrm{~m}$ from the target surface. The working pressure used on the sprayer was $0.414 \mathrm{MPa}$ and the flow rate was $1.0 \mathrm{~m} \mathrm{~s}^{-1}$, resulting in the application rate of $150 \mathrm{~L}$ of spray solution per hectare. Herbicides were sprayed under suitable weather conditions, at the ambient temperature of $25-30{ }^{\circ} \mathrm{C}$ and relative air humidity of $55-75 \%$.

\section{Evaluations}

In both experiments, visual control evaluations (percentage scale, where 0 and 100 represent the absence of injury and death of the plants, respectively) were performed at 21,35 , and 49 days after application $A$ of treatments (DAA). In addition, the number of tillers per plant and plant height (measured from the soil surface to the apex of the last leaf, expressed in $\mathrm{cm}$ ) were measured at 49 DAA on five randomly selected plants in the useful area of the plots. Dry tillers or advanced senescence stages were not considered in tiller count.

\section{Statistical analysis}

In both experiments, the collected data were analyzed using descriptive statistics to determine the central tendency, dispersion, and presence of outliers. After the exploratory analysis, residual analyses were performed to assess the normality of data distribution, homoscedasticity of variance, and independence of errors using ShapiroWilk, Bartlett, and Durbin Watson tests, respectively $(p<0.05)$. When all assumptions were met, analysis of variance was performed separately on data from the two repetitions of the experiments (2018 and 2019). Based on the ratio between the largest and the lowest mean square of the residue, which was $<7$, we considered it appropriate to jointly analyze the data from the repetitions of the experiments, since there was also no interaction effect with the year factor. Following the joint analysis, if the significant effect of the factors studied or of the interaction was found, the means were compared using Tukey's test $(p<0.05)$.

In the control evaluation, the control data without application of the herbicide were disregarded from the analyses using Tukey's test $(p<0.05)$ to meet the assumptions of the analysis of variance. Thus, treatment means were compared with control values using Dunnett's test $(p<0.05)$. In experiment II, treatment means were compared with control values using Dunnett's test $(p<0.05)$. All statistical analyses were performed using $\mathrm{R}$ (R Core Team [R], 2021).

\section{Results and Discussion}

Experiment I: Fractionation and alternation of ACCase inhibitors for sourgrass control

According to the analysis of variance, there were no significant interactions of the agricultural year and treatment factors ( $p<$ 0.05) for all evaluated variables. However, there were significant differences among the treatments; therefore, the means were compared, and results of the two repetitions of the experiments (2018 and 2019) were jointly analyzed. 
The fractionation of clethodim + quizalofop-P-ethyl and clethodim graminicides resulted in higher control percentages than their respective single applications. For quizalofop-P-tefuryl, the fractionation of doses did not increase control efficiency in any treatment (Figure 1).
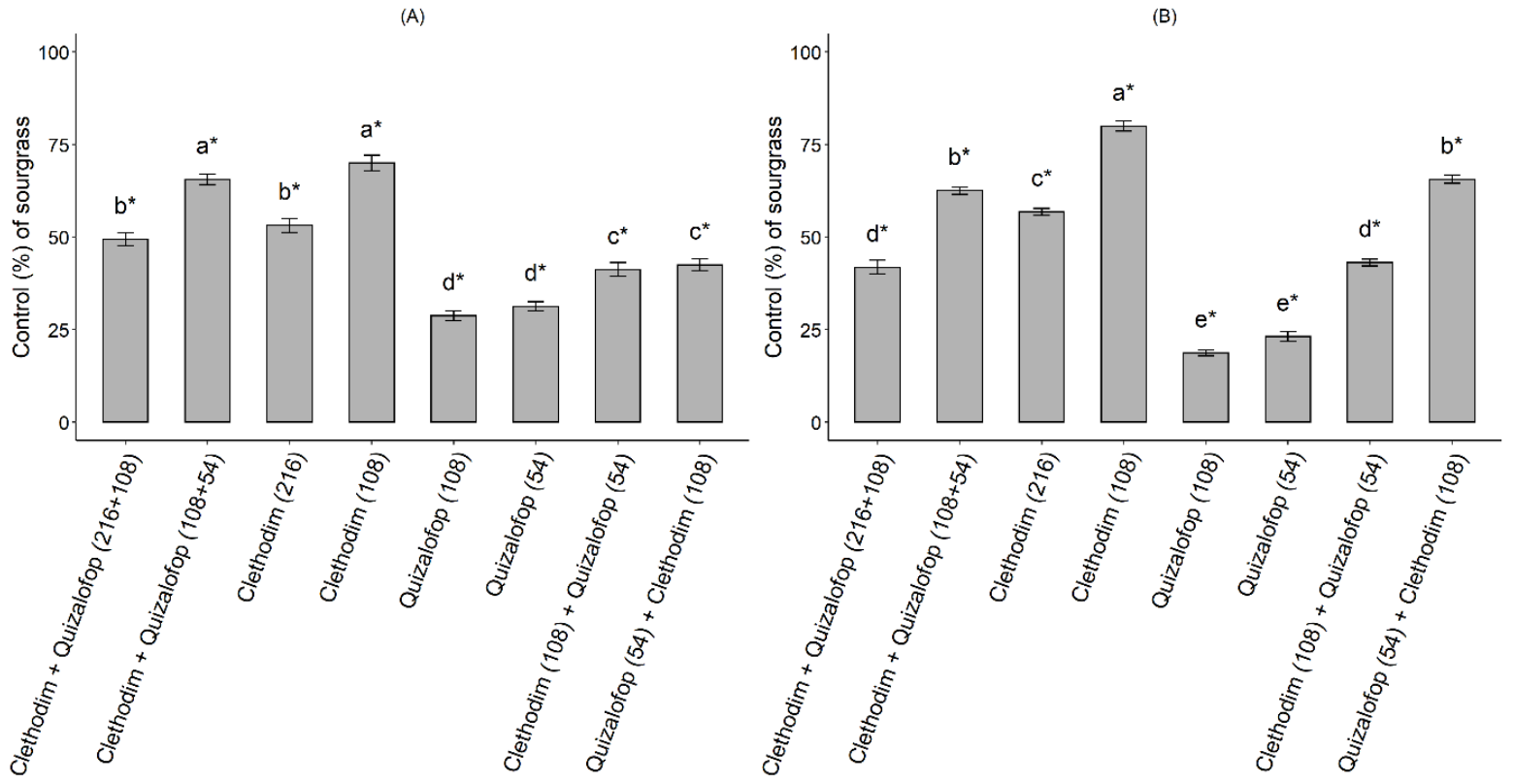

(C)

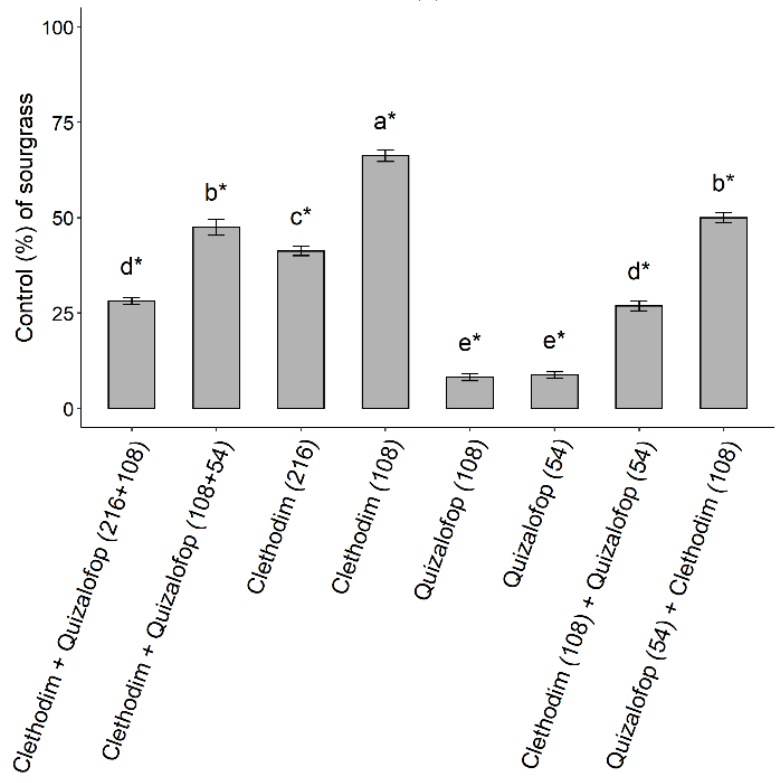

Figure 1. Control (\%) of perennial sourgrass at 21 (A), 35 (B), and 49 days after application $A$ of treatments (DAA) (C) in response to the application of ACCase inhibitors. Means followed by the same letter are not significantly different according to Tukey's test $(p<0.05) .{ }^{*} p<0.05$ compared with control, Dunnett's test. The concentrations of the products used are in $\mathrm{g}$ a.i. ha ${ }^{-1}$. The vertical bars indicate standard deviation. 
Compared with unfractionated treatments, the fractionation of clethodim + quizalofop-P-ethyl and clethodim doses increased control by 16 and $17 \%$, respectively, at 21 DAA (Figure 1A). The best control was achieved by treatment with clethodim + quizalofop-P-ethyl (66\%) and fractionated clethodim (70\%). The other treatments achieved $\leq 50 \%$ control.

At 35 DAA, the control increment with the fractionation of clethodim + quizalofopP-ethyl and clethodim was 20 and 23\%, respectively (Figure 1B). However, the best control was achieved with the fractional application of clethodim (80\%), and this percentage was significantly different from that achieved with the other treatments. Treatment with the fractionation of clethodim + quizalofop-P-ethyl achieved 62\% control, and the application of fractional doses of quizalofop-P-tefuryl followed by clethodim achieved $66 \%$ control. The other treatments achieved $\leq 50 \%$ control.

In the final evaluation at 49 DAA, clethodim fractionation maintained the best efficiency of sourgrass control, ( 66\% control, indicating $25 \%$ higher control than the single application of clethodim at full dose), and this percentage was significantly different from that achieved with the other treatments (Figure 1C). Similar to the trends at 35 DAA, the fractionation of clethodim + quizalofop-P-ethyl and sequential application of fractionated quizalofop-P-tefuryl and clethodim achieved $50 \%$ control. The other treatments achieved $<50 \%$ control.
The order of application of clethodim and quizalofop-P-tefuryl did not affect control at 21 DAA ( 42\%) (Figure 1A). However, at 35 (Figure 1B) and 49 DAA (Figure 1C), the application of quizalofop-P-tefuryl followed by clethodim resulted in $23 \%$ higher control ( $43 \%$ at 35 DAA and $27 \%$ at 49 DAA) than the application of clethodim followed by quizalofop-P-tefuryl.

Quizalofop-P-tefuryl achieved the lowest percentage of control (30\%), regardless of the fractionation and the evaluation period, although the percentage differed from the control value.

The number of tillers per plant was significantly affected by the application of herbicide combinations (Figure 2A). The control treatment showed the highest number of tillers per plant (11 tillers per plant). As a result of the more efficient control observed at 49 DAA in the treatment with fractionated clethodim applications, the number of tillers per plant was the lowest (6.4 tillers per plant). The other treatments, despite differing from the control, showed high regrowth (8-10 tillers per plant).

Finally, plant height was significantly affected by graminicide treatment (Figure 2B). Similar to the observations for other variables, clethodim fractionation achieved the best results, with a $71 \%$ reduction in plant growth compared with the control (plant height, 78 $\mathrm{cm}$ ) (Figure 2B). The application of quizalofopP-tefuryl followed by clethodim and the fractionation of clethodim + quizalofopP-ethyl showed respectively 68 and 66\% greater reductions in plant height than the control treatment. The other treatments, despite differing from the control, plant height reduction of $<50 \%$. 
Experiment II: Effect of Glyphosate Addition to ACCase Inhibitors for the Control of EPSPS Inhibitor-Resistant Perennial Sourgrass

The analysis of variance indicated the presence of a three-way interaction among the factors evaluated for control at 21 and 35 DAA and for the number of tillers per plant. The all main effects were significant for all variables evaluated.
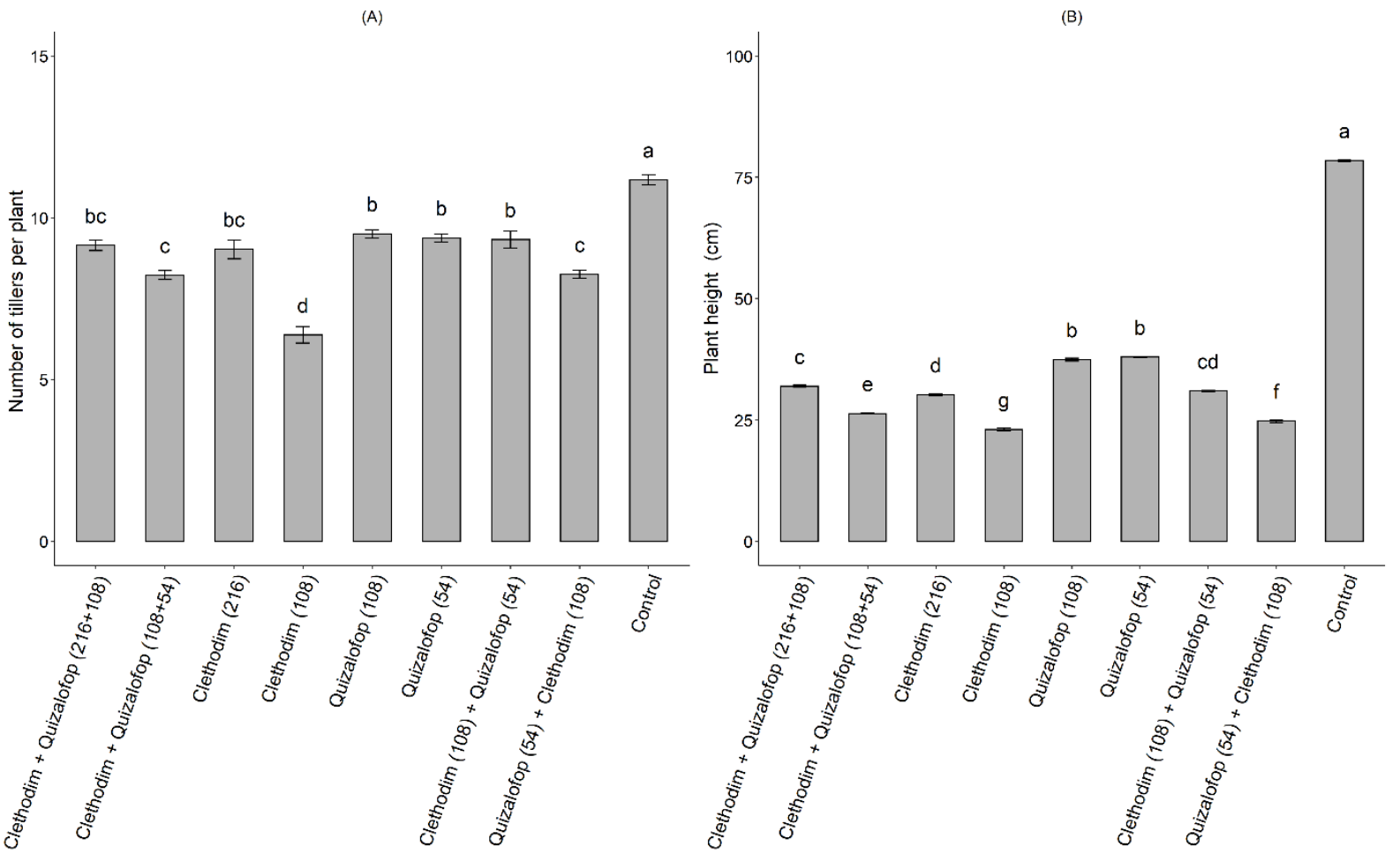

Figure 2. Number of tillers per plant (A) and plant height (B) of perennial sourgrass at 49 days after application $A$ of treatments (DAA) in response to the application of ACCase inhibitors. Means followed by the same letter are not significantly different according to Tukey's test $(p<0.05)$. The concentrations of the products used are in $\mathrm{g}$ a.i. ha ${ }^{-1}$. The vertical bars indicate standard deviation.

Treatments with glyphosate addition resulted in higher control atboth 21 and 35DAA than those without glyphosate addition in the first application (Table 2), and the increase in the control ranged from 10 to $18 \%$. At $21 \mathrm{DAA}$, the application of clethodim + quizalofop-Pethyl and glyphosate achieved $\sim 65 \%$ control when the herbicide was not fractionated. However, the fractional application resulted in $\sim 79 \%$ control. In treatment with the application of clethodim with glyphosate, the fractionation effect was even better, resulting in $87 \%$ control, compared with $61 \%$ control with the single application of the herbicide.

At 35 DAA, the addition of glyphosate to the first application of clethodim resulted in 64 and $93 \%$ control for the unfractionated and fractionated applications, respectively. In the absence of glyphosate, these values 
were reduced to 54 and $77 \%$ of the control, respectively. Thus, glyphosate addition and clethodim fractionation resulted in a $39 \%$ increase in the control of perennial sourgrass resistant to EPSPS inhibitors. However, the application of herbicide clethodim + quizalofop-P-ethyl with glyphosate showed reduced control efficiency, except when the herbicide application was fractionated (78\%).

The interaction of graminicides with glyphosate was not significant for control at 49 DAA. In Figure 3B, the values of mean control achieved by the graminicides and the effect of glyphosate addition are shown. Even in the case of sourgrass resistant to glyphosate, its inclusion in the spray solution resulted in a significant increase in control (by 26\%), particularly with the fractional application of graminicides. In the absence of glyphosate, 33 and 55\% control was achieved with the unfractionated and fractionated applications, respectively, indicating a $22 \%$ increase with fractionation. However, with glyphosate addition, the control was increased to $48 \%$ for the unfractionated application of graminicides and to over $80 \%$ with the fractionated application, indicating a $32 \%$ increment with fractionation.

Table 2

Control of perennial sourgrass at 21 and 35 days after application A of treatments (DAA) in response to the fractionation of graminicides and the addition of glyphosate

\begin{tabular}{|c|c|c|c|}
\hline \multirow{3}{*}{ Graminicide } & \multirow{3}{*}{ Form of application } & \multicolumn{2}{|c|}{ Glyphosate } \\
\hline & & Without & With \\
\hline & & \multicolumn{2}{|c|}{21 DAA } \\
\hline \multirow{2}{*}{ Clethodim + Quizalofop } & Fractionated & $63.75 \mathrm{aBb}^{*}$ & $78.75 a A b^{*}$ \\
\hline & Unfractionated & $48.13 \mathrm{bBa*}$ & $65.00 \mathrm{bAa} a^{*}$ \\
\hline \multirow{3}{*}{ Clethodim } & Fractionated & $68.75 \mathrm{aBa}^{*}$ & $86.88 \mathrm{aAa}^{*}$ \\
\hline & Unfractionated & $51.25 \mathrm{bBa}^{*}$ & $61.25 b A b^{*}$ \\
\hline & & \multicolumn{2}{|c|}{35 DAA } \\
\hline \multirow{2}{*}{ Clethodim + Quizalofop } & Fractionated & $60.63 \mathrm{aBb}^{*}$ & $78.13 a A b^{*}$ \\
\hline & Unfractionated & $40.63 \mathrm{bBb}^{*}$ & $62.50 \mathrm{bAa}^{*}$ \\
\hline \multirow{2}{*}{ Clethodim } & Fractionated & $76.88 \mathrm{aBa}^{*}$ & $93.13 \mathrm{aAa}^{*}$ \\
\hline & Unfractionated & 53.75 bBa* & $64.38 \mathrm{bAa} a^{*}$ \\
\hline
\end{tabular}

Means followed by different lowercase letters within the same dose of herbicide graminicide and glyphosate are significantly different in terms of the effect of fractionation of graminicides according to Tukey's test $(p<0.05)$. Means followed by different uppercase letters in same row are significantly different in terms of the effect of glyphosate according to Tukey's test ( $p<0.05$ ). Means followed by different lowercase letters in italics within the same fractionation level of the graminicide and glyphosate indicate are significantly different in terms of the herbicidal factor according to Tukey's test ( $\mathrm{p}<0.05)$. * $\mathrm{p}<0.05$, Dunnett's test. Unfractionated: clethodim (108 $\mathrm{g}$ a.i. ha-1) and quizalofop (216 g a.i. ha-1) in a single application. Fractionated: two applications of clethodim (108 $\mathrm{g}$ a.i. ha-1) and quizalofop (216 $\mathrm{g} \mathrm{a.i.} \mathrm{ha-1).}$ 


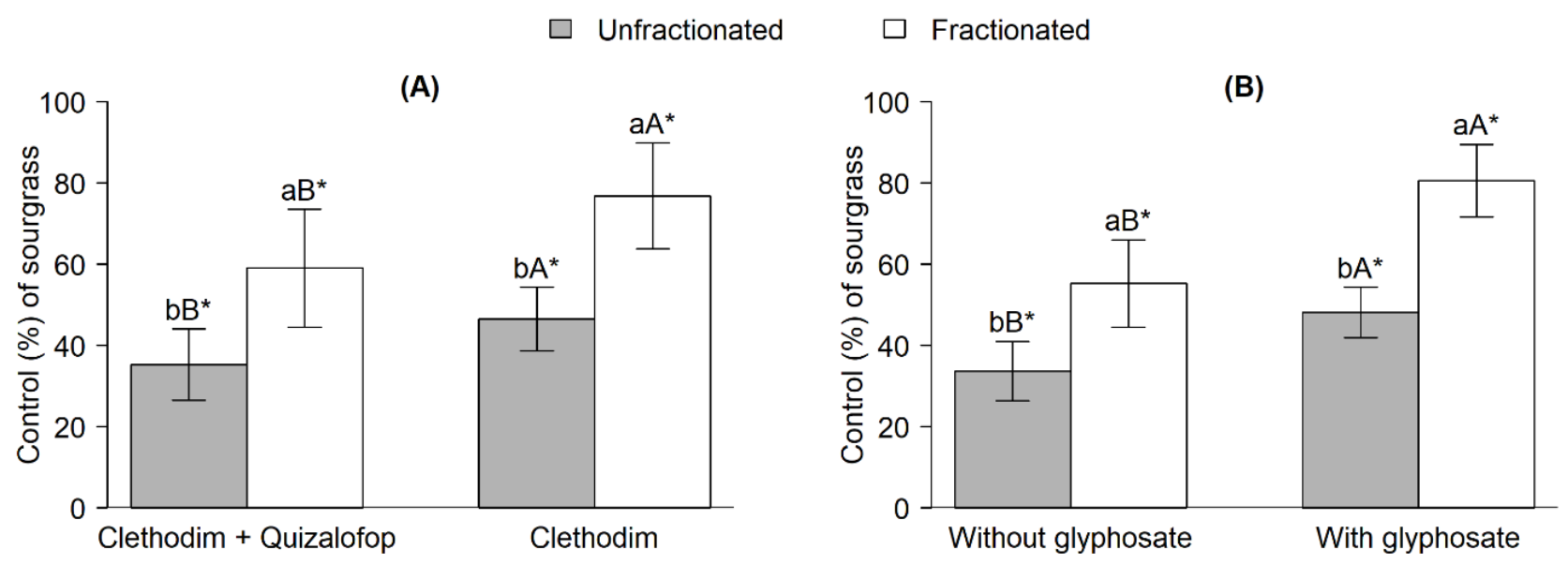

Figure 3. Control of perennial sourgrass at 49 days after application $A$ of treatments (DAA) in response to the fractionation of graminicides (A) and addition of glyphosate (B). Means followed by different lowercase letters within the same dose of graminicide or glyphosate indicate are significantly different in terms of the effect of fractionation of graminicides according to Tukey's test $(p<0.05)$. Means followed by different uppercase letters within the same fractionation level of the graminicide are significantly different in terms of the herbicidal factor of the graminicide or the effect of glyphosate according to Tukey's test $(p<0.05)$. * $p<0.05$, Dunnett's test. Unfractionated: clethodim (108 $\mathrm{g}$ a.i. ha $\left.{ }^{-1}\right)$ and quizalofop (216 $\mathrm{g}$ a.i. ha-1) in a single application. Fractionated: two applications of clethodim (108 $\mathrm{g}$ a.i. ha-1) and quizalofop (216 $\mathrm{g}$ a.i. ha-1). The vertical bars indicate standard deviation.

In the control evaluation at 49 DAA, the fractionation of clethodim + quizalofopP-ethyl resulted in 59\% control, indicating a $24 \%$ increase compared to the value obtained with the single application of the same herbicide (35\%) (Figure 3A). Overall, clethodim showed better control rates, both as a single or fractionated application. However, the fractionation effect was evidently better, with an increase of $30 \%$ (77\% control).

Furthermore, treatments with glyphosate addition in the first application resulted in better results for the number of tillers per plant compared to treatments without glyphosate addition, except for the fractional application of clethodim, which resulted in 6.45 and 5.95 live tillers per plant in the absence and presence of glyphosate, respectively (Table 3 ). In treatment with the application of clethodim + quizalofop-P-ethyl with glyphosate, there were 1.42 and 1.23 live tillers per plant without and with fractionation, respectively. The addition of glyphosate in fractionated applications of clethodim reduced plant growth by approximately $5 \%$ compared with clethodim + quizalofop-Pethyl. However, there were no differences in treatments combining unfractionated graminicide application with glyphosate addition. 
Table 3

Number of tillers per plant of perennial sourgrass in response to graminicide fractionation and glyphosate addition

\begin{tabular}{|cccc|}
\multirow{2}{*}{ Graminicide } & Form of application & \multicolumn{2}{c|}{ Glyphosate } \\
\cline { 3 - 4 } Clethodim + Quizalofop & Fractionated & Without & With \\
\cline { 2 - 4 } & Unfractionated & $9.48 \mathrm{bAa}^{*}$ & $6.25 \mathrm{bBa}^{*}$ \\
\hline Clethodim & Fractionated & $6.45 \mathrm{bAa}^{*}$ & $7.68 \mathrm{aBa}^{*}$ \\
\cline { 2 - 4 } & Unfractionated & $8.92 \mathrm{aAa}^{*}$ & $7.95 \mathrm{bAa}^{*}$ \\
\hline
\end{tabular}

Means followed by different lowercase letters within the same dose of herbicide graminicide and glyphosate are significantly different in terms of the effect of fractionation of graminicides according to Tukey's test $(p<0.05)$. Means followed by different uppercase letters in same row are significantly different in terms of the effect of glyphosate according to Tukey's test ( $p<0.05$ ). Means followed by different lowercase letters in italics within the same fractionation level of the graminicide and glyphosate indicate are significantly different in terms of the herbicidal factor according to Tukey's test ( $\mathrm{p}<0.05)$. * $\mathrm{p}<0.05$, Dunnett's test. Unfractionated: clethodim (108 $\mathrm{g} \mathrm{a.i.} \mathrm{ha-1)} \mathrm{and} \mathrm{quizalofop} \mathrm{(216} \mathrm{g} \mathrm{a.i.} \mathrm{ha-1)}$ in a single application. Fractionated: two applications of clethodim (108 $\mathrm{g}$ a.i. ha-1) and quizalofop (216 $\mathrm{g}$ a.i. ha $\left.{ }^{-1}\right)$.

The interaction of graminicides $x$ glyphosate was not significant for the plant height of sourgrass. In Figure 4B, mean values of plant height in graminicides treatments with or without glyphosate addition are shown. Glyphosate addition reduced the plant height of sourgrass at the end of the evaluation (Figure 4B). In the absence of glyphosate, plant height was approximately 30 and $26 \mathrm{~cm}$ under the unfractionated and fractionated applications of graminicides, respectively, and with the addition of glyphosate to the first application, the plant height was reduced to approximately 28 and $22 \mathrm{~cm}$, respectively. All treatments differed from the control treatment $(81 \mathrm{~cm})$.
Fractionation of the herbicides clethodim and clethodim + quizalofop-P-ethyl resulted in less regrowth compared to the single application (Figure 4A). The plant height was approximately $30 \mathrm{~cm}$ with unfractionated clethodim + quizalofop-P-ethyl application and $26 \mathrm{~cm}$ (13\% reduction) with fractionated application. Plant height with clethodim application was lower than that with clethodim + quizalofop-P-ethyl application, particularly when the herbicide was fractionated $(22 \mathrm{~cm}$, indicating $21 \%$ reduction from value with the single application). 


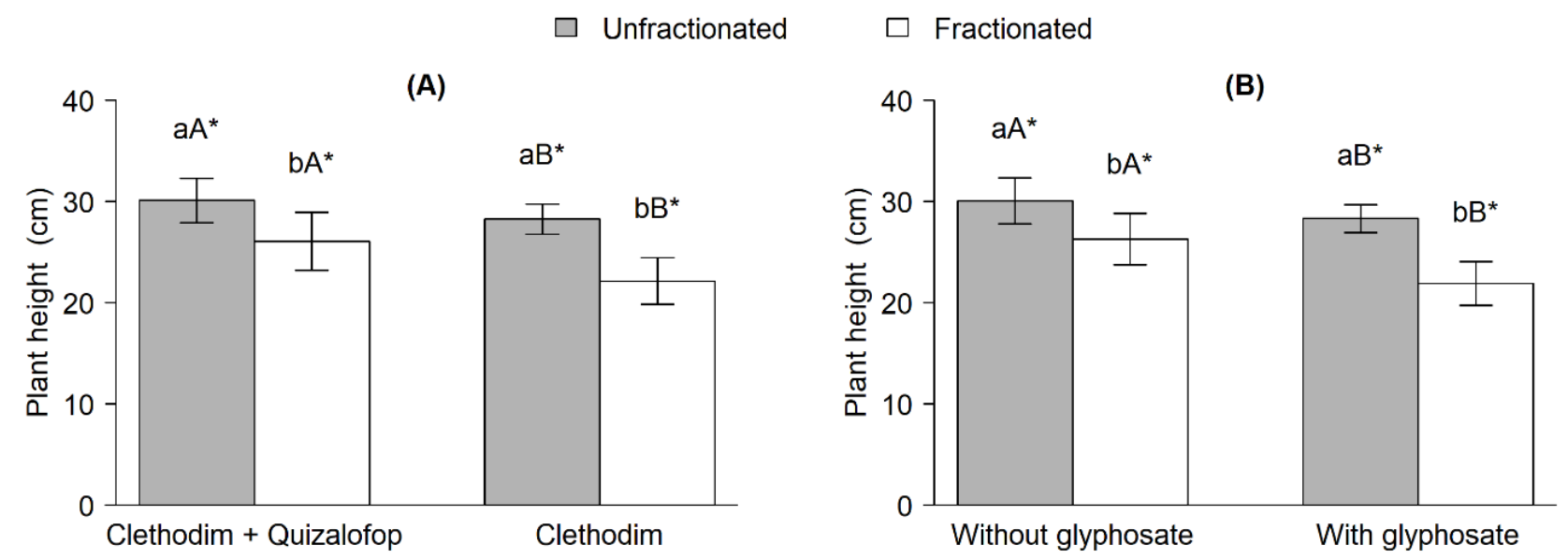

Figure 4. Plant height of perennial sourgrass in response to the fractionation of graminicides (A) and the addition of glyphosate (B). Means followed by different lowercase letters within the same dose of herbicide graminicide or glyphosate indicate are significantly different in terms of the effect of fractionation of graminicides according to Tukey's test $(p<0.05)$. Means followed by different uppercase letters within the same fractionation level of the graminicide indicate are significantly different in terms of the herbicidal factor the graminicide or the effect of glyphosate according to Tukey's test ( $p<0.05)$. ${ }^{*} p<0.05$, Dunnett's test. Unfractionated: clethodim (108 g a.i. ha ${ }^{-1}$ ) and quizalofop (216 $\mathrm{g}$ a.i. $\mathrm{ha}^{-1}$ ) in a single application. Fractionated: two applications of clethodim (108 $\mathrm{g}$ a.i. ha-1) and quizalofop (216 $\mathrm{g}$ a.i. ha-1 ${ }^{-1}$. The vertical bars indicate standard deviation.

In both experiments, the fractionation of clethodim + quizalofop-P-ethyl and clethodim resulted in greater control than their single application (Figures 1 and 3A). ACCase catalyzes the carboxylation of acetylCoA molecules, producing malonyl-CoA, which is a substrate for the biosynthesis of fatty acids, such as phospholipids, which are essential for plants as the major constituents of cell membranes and cuticle (Cobb \& Reade, 2010; Andrade et al., 2018). When ACCase is inhibited by herbicides, such as clethodim and quizalofop, a series of events occur leading to the death of plants (Ye et al., 2018). Because clethodim + quizalofop-P-ethyl and clethodim inhibit lipid synthesis, after the first application of the fractional dose, epicuticular wax deposition on the leaf tissue is reduced, which favors the absorption of the second application of herbicides (Fleck, 1994). Thus, since ACCase-inhibiting herbicides face difficulties in overcoming the cuticular barrier (Bromilow, Chamberlain, \& Evans, 1990), a strategy to increase the control of perennial plants may be to split the dose of graminicides.

The addition of glyphosate to clethodim + quizalofop-P-ethyl increased in the control of sourgrass, both in single and fractionated applications. Although certain glyphosate-resistant graminaceous weeds, such as sourgrass and ryegrass (Heap, 2021), may limit the translocation of applied herbicides (hijacking in vacuole) (Powles \& Yu, 2010), glyphosate can reach the site of action (EPSPS). Thus, when combined with ACCase inhibitors, glyphosate can enhance grass 
control, even against species resistant to glyphosate (Takano, Oliveira, Constantin, Silva, \& Mendes, 2018). Furthermore, glyphosate is known to promote the control of other weed species of crops.

Based on the results of the two experiments, the fractionated application of clethodim achieved superior final control results than the combination of clethodim + quizalofop-P-ethyl and the single application of quizalofop-P-tefuryl (Figures 1C and 3A). These differences in control efficiency against perennial sourgrass between quizalofop and clethodim can be explained, in part, by the physicochemical characteristics of these herbicides, which affect leaf absorption and translocation via the xylem and/or phloem in plants. According to the octanol/water partition coefficient $\left(\log \mathrm{K}_{\mathrm{ow}}\right)$ and electrolytic dissociation constant $(\mathrm{pKa})$ values of the herbicides, quizalofop $\left(\log \mathrm{K}_{\mathrm{ow}}=4.66\right.$ and $\mathrm{pKa}$ $=1.25)$ is absorbed faster than clethodim $\left(\log \mathrm{K}_{\mathrm{ow}}=1.60\right.$ and $\left.\mathrm{pKa}=4.1\right)$ because of its greater affinity with waxes and other nonpolar components of the cuticle. However, its mobility is restricted, and it can only be translocated via the xylem. Clethodim can be translocated via both the xylem and phloem, which may explain its greater control efficiency against perennial sourgrass (Bromilow et al., 1990; Shaner, 2014; Rodrigues \& Almeida, 2018).

Furthermore, the fractionation effect can be affected by the order of application of the chemical groups FOPs and DIMs. In the present study, the application of quizalofopP-tefuryl followed by clethodim achieved superior control of sourgrass compared with the application of clethodim followed by quizalofop-P-tefuryl, both at 35 (Figure 1B) and 49 (Figure 1C) DAA. Most FOPs have a high $\log \mathrm{K}_{\text {ow }^{\prime}}$ which favors their absorption by nonpolar cuticles, although their translocation is limited (Bromilow et al., 1990). For instance, after $72 \mathrm{~h}$ of its application in Setaria viridis (L.) P. Beauv., 98.18\% of fluazifop-P-butyl was retained in the leaf on which it was applied and only $0.23 \%$ had been translocated to the root meristems (Carr, Davies, Cobb, \& Pallett, 1986). Therefore, when applied first, quizalofop-P-tefuryl can loosen the waxes and enable faster leaf damage, mainly through accumulation in the leaf. These injuries mobilize energy reserves for the recovery of injured leaves and the growth of new leaves (Cobb \& Reade, 2010).

In addition to the differences between absorption and translocation, DIM and FOP differ interms of plant control depending on the sensitivity of the species and the differential metabolic capacities of these groups (Burton et al., 1991). In the present study, for sourgrass control, the same doses of each commercial graminicides were considered. However, the concentration of the active ingredient in these formulations was not consistent. In their respective commercial products, the doses used for clethodim contained a higher concentration of active ingredients than those used for quizalofop, alone or in combination with clethodim. Nonetheless, the control efficiency provided by the mixture was inferior to that provided by the isolated application of clethodim, indicating a greater efficiency of clethodim against the studied sourgrass population. However, the sensitivity of ACCase to graminicides varies across weed species and biotypes. In corn plants, Burton, Gronwald, Somers, Gengenbach and Wyse (1989) observed 97\% inhibition of ACCase upon exposure to quizalofop at a concentration of $1 \mu \mathrm{mol}$, while at the same 
concentration, clethodim showed inhibition of only $60 \%$. Similarly, in different biotypes of sourgrass, H. L. L. Gomes, Sambatti and Dalazen (2020) found greater control efficiency of quizalofop than that of clethodim. In addition to the affinity of herbicides to the site of action, other processes can explain the differences in the control efficiency of herbicides in a given species or biotype. Powles and Yu (2010) reported 10 cases of resistance to FOP due to the greater activity of cytochrome $\mathrm{P}_{450}$ monooxygenase and only 1 case of resistance to DIM, which indicates that plants are more resistant to herbicides carrying the FOP groups.

In our experiment, the application of clethodim alone showed better efficiency than the application of clethodim + quizalofopP-ethyl mixture (Figures 1C and 3). However, despite these variations in efficiency, the rotation of the chemical groups FOPs and DIMs or a mixture of these herbicides is an important aspect of the prevention and management of weeds resistance to ACCase inhibitors (Powles \& Yu, 2010; Beckie \& Tardif, 2012). Another mechanism of resistance to the chemical groups of ACCase inhibitors may individual mutations at the binding site, rendering the species or biotype specifically resistant to a chemical group (Powles \& Yu, 2010; Beckie \& Tardif, 2012). There have been reports of eight mutations at the ACCasebinding site, which prevented the binding of FOPs, but only three of these mutations impeded inhibition by DIMs. However, the herbicide FOPs and DIMs share only two amino acids that can confer resistance to both groups, namely asparagine and cysteine at positions 2078 and 2088, respectively (Powles \& Yu, 2010).
In sourgrass, cross-resistance was conferred by a tryptophan-to-cysteine point substitution at position 2027 in one of the functional domains (carboxyltransferase), which affected the interaction between haloxyfop/pinoxaden and ACCase, although susceptibility to DIMs was maintained (Takano et al., 2020). However, in the combined application of clethodim + quizalofop-P-ethyl, the two herbicides may compete for biding at the same site of action (substrate acetyl CoA) (Burton et al., 1991), and the binding of one of these herbicides to the enzyme may prevent the binding of the other (Rendina, CraigKennard, Beaudoin, \& Breen, 1990). Since quizalofop is absorbed faster than clethodim, it typically binds the target site first. However, because of its lipophilic nature (affinity for fats), its translocation is restricted to the xylem, which justifies the increased control of the treatment composed of clethodim alone compared to the combination of clethodim and quizalofop-P-ethyl (Bromilow et al., 1990; Shaner, 2014; Rodrigues \& Almeida, 2018).

Although all treatments differed from the control treatment in both experiments, the plants could not be completely controlled at the end of the evaluation period in any treatment, demonstrating the difficulty of controlling perennial sourgrass. Plant regrowth was common, demonstrating the need for additional interventions to control the newly emerged tillers. Therefore, integrated management is imperative to manage sourgrass plants at the early stages of development. Otherwise, the producers may face difficulties in controlling this species, entailing a greater financial burden. 


\section{Conclusion}

The fractional application of graminicides and the addition of glyphosate can help control perennial sourgrass plants resistant to EPSPS inhibitors. The fractionation of clethodim + quizalofop-P-ethyl and clethodim increased control efficiency by respectively $20-24$ and $25-30 \%$ compared with the unfractionated applications of these herbicides. Fractionated clethodim enhanced the control and reduced the regrowth and height of sourgrass plants. The order of application of the chemical groups FOPs and DIMs affected the control efficiency, with better results obtained through the application of quizalofop-P-tefuryl followed by clethodim. The addition of glyphosate enhanced the action of graminicides, particularly when fractionated, with a $26 \%$ increase in control efficiency, resulting in satisfactory control (>80\%).

\section{References}

Andrade, A., Tulmann, A., Neto, Tcacenco, F. A., Marschalek, R., Pereira, A., Oliveira, A. M., Neto,... Noldin, J. A. (2018). Development of rice (Oryza sativa) lines resistant to aryloxyphenoxypropionate herbicides through induced mutation with gamma rays. Plant Breeding, 137(3), 364-369. doi: 10.1111/pbr.12592

Beckie, H. J., \& Tardif, F. J. (2012). Herbicide cross resistance in weeds. Crop Protection, 35(1), 15-28. doi: 10.1016/j. cropro.2011.12.018

Bromilow, R. H., Chamberlain, K., \& Evans, A. A. (1990). Physicochemical aspects of phloem translocation of herbicides. Weed
Science, 38(3), 305-314. doi: 10.1017/ S0043174500056575

Burton, J. D., Gronwald, J. W., Keith, R. A., Somers, D. A., Gengenbach, B. G., \& Wyse, D. L. (1991). Kinetics of inhibition of acetylcoenzyme A carboxylase by sethoxydim and haloxyfop. Pesticide Biochemistry and Physiology, 39(2), 100-109. doi: 10.1016/0048-3575(91)90130-E

Burton, J. D., Gronwald, J. W., Somers, D. A., Gengenbach, B. G., \& Wyse, D. L. (1989). Inhibition of corn acetyl-CoA carboxylase by cyclohexanedione and aryloxyphenoxypropionate herbicides. Pesticide Biochemistry and Physiology, 34(1), 76-85. doi: 10.1016/0048-3575 (89)90143-0

Carr, J. E., Davies, L. G., Cobb, A. H., \& Pallett, K. E. (1986). Uptake, translocation and metabolism of fluazifop-butyl in Setaria viridis. Annals of Applied Biology, 108(1), 115-123. doi: 10.1111/j.1744-7348.1986. tb01972.x

Cobb, A. H., \& Reade, J. P. H. (2010). Herbicides and plant phisiology. London: Wiley.

Fadin, D. A., Tornisielo, V. L, Barroso, A. A. M., Ramos, S., Reis, F. C. dos, \& Monquero, P. A. (2018). Absorption and translocation of glyphosate in Spermacoce verticillata and alternative herbicide control. Weed Research, 58(5), 389-396. doi: 10.1111/ wre.12329

Fleck, N. G. (1994). Doses reduzidas de herbicidas de pós-emergência para controle de papua em soja. Planta Daninha, 12(1), 21-28. doi: 10.1590/S01 00-83581994000100004

Gazola, T., Belapart, D., Castro, E. B., Cipola, M. L., F., \& Dias, M. F. (2016). Características 
biológicas de Digitaria insularis que conferem sua resistência à herbicidas e opções de manejo. Científica, 44(4), 557567. doi: 10.15361/1984-5529.2016v44n 4p557-567

Gilo, E. G., Mendonça, C. G., Santo, T. L. E., \& Teodoro, P. E. (2016). Alternatives for chemical management of sourgrass. Bioscience Journal, 32(4), 881-889. doi: 10.14393/BJ-v32n4a2016-32786

Gomes, H. L. L., Sambatti, V. C., \& Dalazen, G. (2020). Sourgrass control in response to the association of 2,4-D to Accase inhibitor herbicides. Bioscience Journal, 36(4), 1126-1136. doi: 10.14393/BJ-v36 n4a 2020-47895

Gomes, L. J. P., Santos, J. I., Gasparino, E. C., \& Correia, N. M. (2017). Chemical control and morphoanatomical analysis of leaves of different populations of sourgrass. Planta Daninha, 35, e017158021. doi: 10. 1590/S0100-83582017350100008

Heap, I. (2021). The international survey of herbicide resistant weeds. Retrieved from www.weedscience.com

Heap, I., \& Duke, S. O. (2018). Overview of glyphosate-resistant weeds worldwide. Pest Management Science, 74(5), 10401049. doi: $10.1002 / p s .4760$

Lancaster, Z. D., Norsworthy, J. K., \& Scott, R. C. (2018). Sensitivity of grass crops tolow rates of quizalofop. Weed Technology, 32(3), 304-308. doi: 10.1017/wet.2018.14

Lopes Ovejero, R. F., Takano, H. K., Nicolai, M., Ferreira, A., Melo, M. S. C., Cavenaghi, A. L.,... Oliveira, R. S. (2017). Frequency and dispersal of glyphosate-resistant sourgrass (Digitaria insularis) populations across Brazilian agricultural production areas. Weed Science, 65(2), 285-294. doi: 10.1017/wsc.2016.31

Mendonça, G. S., Martins, C. C., Martins, D., \& Costa, N. V. (2014). Ecophysiology of seed germination in Digitaria insularis ((L.) Fedde). Revista Ciência Agronômica, 45(4), 823-832. doi: 10.1590/S1806-669 02014000400021

Nandula, V. K., Poston, D. H., Reddy, K. N., \& Koger, C. H. (2007). Formulation and adjuvant effects on the absorption and translocation of $14 \mathrm{C}$-clethodim in wheat (Triticum aestivum L.). Weed Biology and Management, 7(4), 226-231. doi: 10.1111/j.1445-6664.2007.00260.x

Powles, S. B., \& Yu, Q. (2010). Evolution in action: plants resistant to herbicides. Annual Review of Plant Biology, 61(1), 317-347. doi: 10.1146/annurev-arplant-042809-11 2119

R Core Team (2021). R: a language and environment for statistical computing. Vienna, Austria: R Foundation for Statistical Computing.

Radwan, D. E. M., \& Soltan, D. M. (2012). The negative effects of clethodim in photosynthesis and gas-exchange status of maize plants are ameliorated by salicylic acid pretreatment. Photosynthetica, 50(2), 171-179. doi: 10.1007/s11099012-0016-8

Rendina, A. R., Craig-Kennard, A. C., Beaudoin, J. D., \& Breen, M. K. (1990). Inhibition of acetyl-coenzyme A carboxylase by two classes of grass-selective herbicides. Journal of Agricultural and Food Chemistry, 38(5), 1282-1287. doi: 10.1021/jf00095a029 
Rodrigues, B. N., \& Almeida, F. S. (2018). Guia de herbicidas. Londrina: Produção Independente.

Shaner, D. L. (2014). Herbicide handbook. Champaign: Lawrence.

Silva, W. T., Karam, D., Vargas, L., \& Silva, A. F. (2017). Alternativas de controle químico para capim-amargoso (Digitaria insularis) na cultura do milho. Revista Brasileira de Milho e Sorgo, 16(3), 578586. doi: 10.18512/1980-6477/rbms. v16n3p578-586

Silveira, H. M., Langaro, A. C., Álcantara-de la Cruz, R., Sediyama, T., \& Silva, A. A. (2018). Glyphosate efficacy on sourgrass biotypes with suspected resistance collected in GR-crop fields. Acta Scientiarum Agronomy, 40(1), 69-74. doi: 10.4025/actasciagron.v40i1.35120
Takano, H. K., Melo, M. S. C., Ovejero, R. F. L., Westra, P. H., Gaines, T. A., \& Dayan, F. E. (2020). Trp2027Cys mutation evolves in Digitaria insularis with cross-resistance to ACCase inhibitors. Pesticide Biochemistry and Physiology, 164(1), 1-6. doi: 10.1016/j. pestbp.2019.12.011

Takano, H. K., Oliveira, R. S., Jr., Constantin, J., Silva, V. F. V., \& Mendes, R. R. (2018). Chemical control of glyphosateresistant goosegrass. Planta Daninha, 36, e018176124. doi: 10.1590/S010083582018360100055

Ye, F., Ma, P., Zhang, Y. Y., Li, P., Yang, F., \& Fu, Y. (2018). Herbicidal activity and molecular docking study of novel ACCase inhibitors. Frontiers in Plant Science, 9(1850), 1-10. doi: 10.3389/fpls.2018.01850 